\title{
The Partnership of Maritime Tourism Management in Kapoposang Island Pangkajene Regency
}

\author{
${ }^{1}$ BADU AHMAD, ${ }^{2}$ FARAMITHA SRI PUJI RAHAYU THAHIR \\ ${ }^{1,2}$ Fakultas IImu Sosial dan Ilmu Politik, Universitas Hasanuddin \\ email: ${ }^{1}$ baduahmad7@gmail.com; 2 mithaqyu6@gmail.com
}

\begin{abstract}
The form of cooperation between public and private has now become the main reference in fulfilling the availability of infrastructure to improve the service and needs of society, especially for those who are living on the island. This article aims to analyze the forms of partnership that exists between the office of Culture and Tourism of Pangkep with PT. Makassar Tirta Tourism, as well as the public benefit to be derived from such form of cooperation. This article uses a qualitative approach through observation, interviews and documentation of the informants who were directly involved in the implementation of these activities. The process of data analysis includes data reduction, data presentation, and conclusion or verification. This article shows that the form of partnership is only focused on the management and empowerment of marine tourism which involves only one side of the party in the implementation of partnership. The contribution or profit obtained by each partner is not comparable with one another. This is influenced by the lack of tourists who visit the island, therefore some improvements in providing the best tourists' service is needed. Viewing from the benefits for the community, this cooperation helps to raise the economic level of the community, but it is opposed to their social life where they have difficulties in accessing education and health.

Keywords: public private partnership, community empowerment, island community,
\end{abstract}

\section{Introduction}

The governance for development and public service according to the paradigm of good governance is not only done by the government based on rule government (legality) or the interests of local government. It emphasizes processes and procedures, which in the preparatory process of planning and formulation of a policy should always prioritize solidarity and involving all stakeholders in conducting public affairs. Incorporating the spirit of entrepreneurship into the system of state administration (reinventing government) is part of the concept of publicprivate partnership spearheaded by Osborne (1992). It becomes an alternative solution in optimizing asset management area that can improve the performance of the service and welfare of the community. Parente (2006) discloses this as an important aspect of partnership work and illustrates the form and benefits provided to each party involved.

The partnership between the government and the private sector or publicprivate partnership (PPP) is, indeed, an ideal form since it provides space for private sector participation and the community to participate in promoting government development programs through a partnership. The terminology of a private government partnership in Indonesia began with the issuance of Presidential Decree No.67/2005 on Government Cooperation with Business Entities in the Provision of Infrastructure, which stipulated that implementation of PPP is conducted on a fair, open, transparent and competitive principle.

This public-private partnership is also

Received: March 22, 2017, Revision: April 25, 2017, Accepted: May 19, 2017

Print ISSN: 0215-8175; Online ISSN: 2303-2499.

Accredited by DIKTI. SK Kemendikbud, No.040/P/2014, valid 18-02-2014 until 18-02-2019, Indexed by DOAJ 
an agreement between the archipelagic community represented by the government and the private sector to provide travel infrastructure and public service facilities in Kapoposang Island. This partnership program is the desire of the Indonesian government to promote and accelerate regional development, as well as to meet the availability of facilities and infrastructure in fulfilling the basic needs of the community, including in promoting marine tourism destinations, such as marine areas in Kapoposang Island in Pangkajene Islands Regency (Pangkep) South Sulawesi Province.

The form of cooperation between the government and the private sector is now become the main reference in fulfilling the availability of infrastructure facilities in improving the service and the various needs of the community, especially for the people of Kapoposong Island. The development of tourism is aimed to improve the sustainable welfare of local people, in addition to getting entertainment from the natural treats of coastal and ocean environment, and also the expectation that tourists would participate directly in developing environmental conservation to preserve coastal areas in the present and the future.

The potential of marine and coastal tourism can be explored optimally by various development approaches and socio-economic policies based on local cultural values so that the cultural roots of local coastal communities could give the color of exotic tourism development and the preservation of the coastal environment. Law no. 27/2007 explains that the management of marine tourism on small islands is directed to the protection, preservation, utilization of coastal areas by utilizing social capital of society that adapt to environmental changes and biological environment conservation in a sustainable manner.The strategic elements of maritime tourism development and management include: (1) local government policy, (2) social capital empowerment of coastal communities, (3) development of e-coastal tourism integrated with PPP system, (4) coastal tourism infrastructure development, 5 ) innovation of tourism facilities, (6) implementation of PPP based empowerment and local cultural wisdom. Those are in line with Asker's opinion (2010), which stated that there are three principles of communitybased tourism, namely: (a) community empowerment, (b) prioritizing community culture, (c) prioritizing coastal environment
conservation.According to Schubeler (1996), private sector involvement includes private sector capital flows, management capabilities, and technical skills which can change the overall environment of the public provision system.Efforts made by the Pangkep government to encourage the economic improvement of island people is to partner with the private sector.

Context of PPP implementation in this article is examining the form of partnership that exists between Culture and Tourism Office of Pangkajene Islands Regency with PT. Makassar Tirta Wisata with the question of: what are the benefits to be gained from the partnership form among the government, private sector and community. The partnership in question is all forms of participation from government, private, and community that related to and work together in the management of tourism destinations, especially marine tourism in Kapoposang Island.Department of Culture and Tourism has made cooperation agreement with PT. Makassar Tirta Wisata on the management contract of marine tourism object on the island of Kapoposang with Number: 420/1 / KSD / I / 2011 and Number: 003 / MDC / MTW / I / 2011, based on the foundation of Permendagri No.17 / 2007 on Guidance of Technical Management Regional Property and Local Regulation No.12 / 2008 on Management of Regional Property. In that agreement, the first party is the Regional Government as the owner of a marine tourism object in Kapoposang Island which has a goal to manage the property in order to efficiently and successfully providing optimum services to the community in the form of recreation and tourism facilities that can contribute to the increase of the Original Regional Revenue $(P A D)$, and also to provide multiplier effects on the socio-economic empowerment of the community.

Based on the results of observation, there are several problems related to Kapoposang Island tourism management, namely: (1) low community participation in the development of marine tourism objects; (2) low ability of the island community in developing their economic activities; (3) low community involvement in marine tourism drafting process. Results of the observations lead to a research that aims to analyze the forms of partnership that existed so far between the Office of Culture and Tourism Pangkep with PT Makassar Tirta Wisata. In addition, the article analyzes the benefits 
obtained by the parties after the program improvement and development of island potential for the sustainability of socioeconomic life of the island's community.

\section{Methodology Research}

The research location of partnership in marine tourism management is conducted in Kapoposang Island, Pangkep regency. The researcher chose that location with the reason to analyze the form of partnership that exist between the government and private sector, and what benefit the community will gain from that partnership. This article uses qualitative approach with case study aimed to collect data, extract the meaning, and gain an understanding of the case.

The data in this article obtained through informants who are directly related to the activities of marine tourism management, including: Secretary of Culture and Tourism Office of Pangkep District, Head of Tourism Business, Chairman of Makassar Diving Center (MDC) representing PT. Makassar Tirta Wisata, island manager, local community and tourists/visitors. Data were also obtained through the events or phenomena that occur in the location that corresponds to the focus of the research study. The other data sources are documents related to research focus. Data collection techniques used was interviews, observation, and documentation.

Data analysis techniques used in this article is Miles and Huberman (1992) model, which suggests that the activities in qualitative data analysis are done interactively and continuously to complete, so that it is saturated. There are three activities in data analysis, namely: data reduction, display data, and conclusion drawing/verification.

\section{Concept of Partnership}

Savas (1987) defines partnerships as the division of responsibilities, rights and duties between local communities and governments as a decentralized approach in decisionmaking processes involving local users equal to the government. Furthermore, Savas proposed the form of partnership with the involvement of the private sector as a dynamic concept in serving and fulfilling the needs of the public that was originally undertaken by government agencies. This cooperation known as Public Private Partnership (PPP) is a long-term construction agreement between the government and the private sector to meet the needs of public facilities. Through this partnership, the public and private sectors provide their own skills and assets in providing services or facilities for the use of the general public (Alfen, et al., 2009). Furthermore, Grimsey and Lewis (2004) stated that Public Private Partnership emerged as an important model used by the government to fill the infrastructure gap since it offers a lot of benefits. The government, then, tries to overcome the lack of infrastructure and/or improve organizational efficiency. Whereas, Parente (2006) argues that Public Private Partnership is an agreement or contract between unity of society represented by government and private sector to provide public service with source of finance borne by service user instead of taxpayer with the condition of: (1) the private sector is functioning government for a certain period; (2) the private sector get compensation from the implementation of these functions either directly or indirectly; (3) the private sector is responsible for the risks of performing the function; (4) public facilities may be used by private sector.

Meanwhile, according to Selamat (2013), there are three main pillars that support the ability of a nation in implementing partnerships and required to realize good governance, namely: (1) the conception of governance is basically a state activity, but then further involves the private and institutional sectors of community; (2) private sector actors include private companies which actively interact in market systems, such as trade processing industries, banking and cooperatives, including informal sector activities; (3) the civil society in the context of the state is essentially exists between or in between the government and the individual, including both individuals and societal groups that interact socially, politically and economically.

From the perspective of private participation, according to Schubeler (1996: 32), private sector involvement includes private sector capital flows, management capabilities, and technical skills which can change the overall environment of the public provision system. The cooperation between the two parties immediately demand for the benefit result for each and also have to pay attention to what is needed by the community.

\section{Forms of Partnership}

In theory, the Public Private Partnership (PPP) is an ongoing synergy in development 
projects to improve public services with the government as regulator and the private sector responsible for the implementation of a project from design, construction, maintenance and operation. The forms and schemes of cooperation in the PPP can be: (1) BOT (build operate, transfer) ie the private party build, operate the facility and return it to the government after the contract term is completed; (2) BTO (build, transfer, operate) ie the private party build, deliver its assets to the government and operate the facility until the contract expires; (3) ROT (rehabilitate, operate, transfer) ie private party improve, operate the facility and bring it back to the government after the contract is ended; (4) BOO (build, own, operate) ie private party build, the private owner of the facility and to operate and maintain; (5) O \& M (operation and maintenance) ie the government build, private operate and maintain (Kumar and Prasad, 2004).A broad classification of PPP spectrum models has emerged to enable private sector participation in providing infrastructure and service facilities, as in the following table 1

Furthermore, the basic form of partnership in the provision of public services could be as follows: (a) joint operation of the regional government, regional governmentowned enterprises, together with the private sector managing a business without forming a new one; (B) a joint venture which is a regional government or a regional stateowned enterprise jointly establishes a joint venture company without eliminating the existence of the institutions involved.

\section{Benefits and Purpose of Partnership}

Based on Presidential Regulation No. 67/2005, the implementation of Public Private Partnership (PPP) is based on fair, open, transparent and competitive principles in order to achieve benefits of: (1) low market price assurance; (2) increase public acceptance of Public Private Partnership projects; (3) encouraging the ability of financial institutions to provide financing without sovereign guarantees; (4) reduce the risk of project failure; (5) prevent government officials from corruption, collusion and nepotism practices. While the objectives of Public Private Partnership include: (a) providing sufficient funding needs in a sustainable manner through the mobilization of private funds; (b) increasing the quantity, quality, and efficiency of services through healthy competition; (c) improving the quality of management and maintenance in the provision of infrastructure; (d) increasing the purchasing power of service users.

The government's policy is in line with the views of Abriany (2002), which said private sector involvement in public service benefits are: (a) accelerating investments; (b) improving the efficiency of utilization of public facilities; (c) granting better financial management; (d) diverting government resources and more prioritize on social infrastructures. On the other hand, the benefits gained by the government in carrying out partnerships for development, among others are: to increase the sense of ownership for the community against the development program, to reduce the barriers of innovation programs, to increase community participation, to improve community skills in addressing problems, to hold programs according to community needs, to reduce dependency on APBD (regional bugdet), and to realize good governance and clean government.

\section{The concept of Marine Tourism}

According to Chadwick (1994) there are three important concepts used simultaneously to define tourism, namely: first, the movement (spatial) of the population; second, the economic sector or activities that produce

Table 1

Classification of Spectrum PPP Model

\begin{tabular}{lccccl}
\hline Option & $\begin{array}{c}\text { Aset } \\
\text { Ownership }\end{array}$ & O \& M & $\begin{array}{c}\text { Capital } \\
\text { Investment }\end{array}$ & $\begin{array}{c}\text { Commercial } \\
\text { Risk }\end{array}$ & Duration \\
\hline Management Contract & Public & Private & Public & Public & $3-5$ years \\
Lease & Public & Private & Public & Shared & $8-15$ years \\
Concession BOT & Public & Private & Private & Private & $25-30$ years \\
BOOT/BOO & Private & Private & Private & Private & $20-30$ years \\
& Public & & & & \\
\hline
\end{tabular}


and reproduce goods and services; third, a system that interacts with human beings, the need to travel out of the community and services in intangible and tangible products that arise in response to those needs. These three concepts form an integrated basis for creating a tourism phenomenon. According to William J. Parente (2006) this is an important aspect of partnership cooperation.

The management of maritime tourism is expected to improve the utilization of the natural environment, environmental sound, and keep the sustainable development without eliminating the cultural aspect by prioritizing saving and preserving marine natural resources. It is also revealed by Asker (2010) who stated that there are three principles of community-based tourism, namely empowerment, promoting culture and promoting the environment. In addition to these three principles, Haussler and Strasdas (2002) added another principle which said that the greatest benefit should be enjoyed by community. Other important principle is the educational element for the community and visitors to understand about the importance of protecting the nature and culture.

Using the PPP model classification quoted from Kumar and Prasad expositions (2004) which enabling private sector participation in the provision of infrastructure and service facilities, the discussion on the tables includes aspects of contract management, leasing, BOT and BOOT concession or BOO. These aspects are respectively related to aspects such as asset ownership, operations and management, capital investment, commercial risk and contract term. Such classification is expected to be able to see the importance of partnerships established in the management of conservation in coastal areas of small islands, particularly Kapoposang Island, with the question of whether it has already met the expectation of government as the owner of the asset and the private sector which manages the asset. The direction and flow of this article are presented in the "thinking framework" in figure 1.

Kapoposang Island has several potentials, among others; Biodiversity, especially coral reefs that surround the island, natural beauty of pristine forest, white sandy beaches, pine trees, coconut trees and Santigi wood, Konde birds, Canary Crab, Hawksbill that make Kapoposang Island its nesting place. These potential is attracted tourist to visit the island of Kapoposang. Tourist attraction and it needs to be developed. Seeing the potential of the island, PT. Makassar Tirta Wisata has done preservation and also maintenance of maritime area and tourist area, although it has not yet received the official permit to managing the island. The tourist area of the island is still owned fully by government of Pangkep.

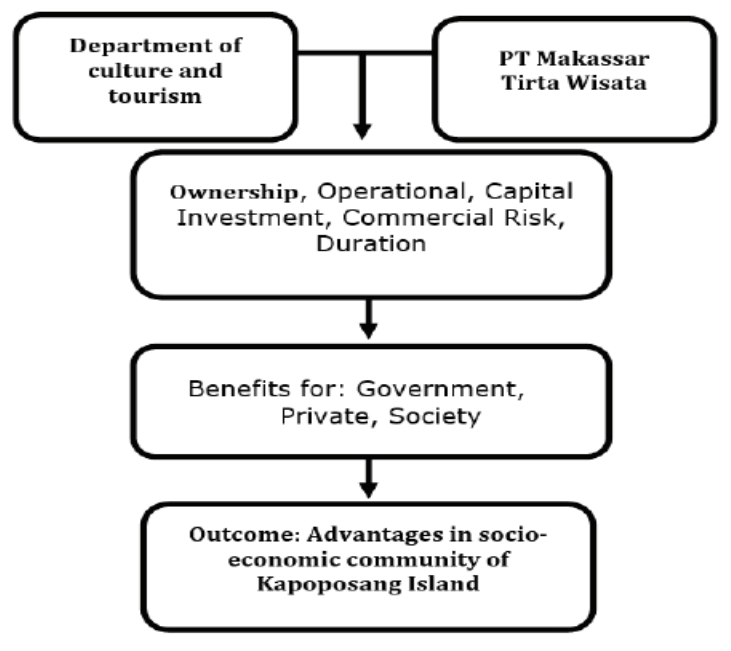

Figure 1

Thinking Framework

The agreement or contract of Kapoposang Island management was officially started in 2011, where the first party is the local government as the owner of Kapoposang Island. It is used as a marine tourism object with the aim of efficiently and effectively manage the island to provide optimum services to the community. These services are in the form of providing recreation and tourism facilities that can contribute to the increase of Local Original Revenue (Pendapatan Asli Daerah), and also able to provide multiplier effect on the economic empowerment of the community. The second party is PT. Makassar Tirta Wisata, carries out tourism management as well as preservation of maritime area by maintaining the assets of local government and assisting the community in increasing their socioeconomic level especially Kapoposang Island community. The contract of this cooperation agreement will last for 30 years and has been running for five years. Currently, the cooperation has entering its sixth year, which will require a revision and reset the value of the contribution for the next five years of the second period.

Based on the result of the research, the partnership form analyzed shows that the 
form of partnership between the Department of Culture and Tourism with PT Makassar Tirta Wisata is included in the Concession BOT (build operate, transfer) category, where in the handling of development operation requires more complex preparedness especially build commitment and Trust between local government and private parties in infrastructure development for various sectors of public interest. Viewed from the ownership (asset owning), Kapoposang Island is one of the island's assets owned by Pangkep government, where the local government gives permission in managing the sea as well as maintaining and preserving marine areas, especially coral reef as part of Kapoposang island which will be managed by PT.Makassar Tirta Wisata (Makassar Diving Center). The government will also renting other assets in the form of four units of rest houses (villas) used in tourist area of Kapososang island. The form of agreement is based on the Minister of Home Affairs regulation No.17/2007 on guidelines for the management of Regional Goods and Local Regulations No.12/2008 on Management of Regional Property. The land area managed is only $25 \%$ of the entire island area, while $100 \%$ of the coastal and marine areas managed by PT. Makassar Tirta Wista along with the National Aquaculture Conservation Center (BKKPN), Ministry of Marine Affairs and Fisheries Maros for the preservation of underwater biota.

The result of the research shows that Operation and Maintenance of Kapoposang Island tourism area is fully done by private sector in accordance with the Cooperation of Utilization of Regional Property between the first party (Pangkep local government) and second party (PT.Makassar Tirta Wisata) No.420/1/KSD/I/2011 and No.003/MDC/ MTW/ I / 2011. Hiring local government assets as well as perform maintenance, private parties pay rent in the form of permanent contributions that have been attached to the cooperation agreement, and the union of taxes and levies stipulated in accordance with Regulation No.2/2012. Contractual agreements made by private parties began in 2011 with the first year until the third year as the stage of investment plan and the construction of public facilities in Kapoposang Island. The fourth year and next would be the stage of preservation of tourist areas and coral reefs as well as turtle breeding which considered is successfull.

Meanwhile, from the capital investment side, local government of Pangkajene Islands transferred their assets to the private investment of PT. Makassar Tirta Wisata (in article 8 of Law No.25/2007 on investment), and also rented 4 rest house used in tourist area. While the private sector invested in the form of lodging assets in the tourist area, and cooperate with other private parties in helping to invest their capital for the sake of continuity and prosperity and support of public facilities for the island community.

The result of the research shows that Commercial Risk is not only experienced by the private sector, but Pangkep government also experienced the decrease of profit from the tourists who visit Kapoposang Island. Table 2 shows data of visitor and also profit and retribution obtained by local government and private sector.

\section{Table 2 \\ Visitor Data and Local Government Profit}

\begin{tabular}{ccccc}
\hline Years & \multicolumn{2}{c}{ Visitor } & \multicolumn{2}{c}{ Profit (rupiah) } \\
\hline & Local & Foreign & PT MTW & Pangkep \\
2012 & 274 & 0 & 850.000 .000 & 1.370 .000 \\
2013 & 100 & 36 & 600.500 .000 & 860.000 \\
2014 & 156 & 0 & 400.500 .000 & 690.000 \\
2015 & 94 & 16 & 342.500 .000 & 630.000 \\
\hline
\end{tabular}

Source: Department of Tourism and PT. MTW

Based on the above table, the most obvious commercial risk is the lack of tourists due to seasonal changes seen from west and east winds so that in certain months (around August to March), there are barely tourists visiting Kapoposang island. The impact of the lack of tourists is the decreasing of company's profit and retribution to the local government over the last four years, while private parties are required to make repairs and maintenance of buildings in the form of public facilities as long as the contractual contact is still valid.

Viewed from duration, content of the contract cooperation is last for 30 years. The year 2017 is the second period and the seventh year in the contract of cooperation. However, in this second term of contract there will be re-apply and re-discuss about the rent and tax/levy fees that will be valid for the next 5 years. This is done due to the decline in profit and retribution over the last four years which caused by high sea waves from August to March every year. It made the local and foreign tourists are afraid to cross the sea to go to Kapoposang. The lack of tourists also showed on the economic life of the community, where various tourism 
support facilities such as cafes, restaurants, and lodging experienced under minimum income.

As stated by Ramelan (1997: 26), the granting some of government authority to the private sector to carry out some or all development activities and/or infrastructure operations are expected to encourage the acceleration of public services and improving the welfare of island communities. The development of maritime tourism object in Kapoposang Island is part of the tourism management which is directly related to the service. It requires cooperation with various tourism organizer components, such as government, private party, and community. There are two programs in the development of Kapoposang Island conducted by related stakeholder, namely business program conducted by the government and private and coastal environmental conservation programs to support the increasing quality of tourism, especially in Kapoposang Island. Furthermore, Haryani (2014) explains that the characteristic of a region is the basic capital and attraction for tourism development. Without the typical tourist attraction, tourist satisfaction will not be achieved, although tourism facilities and infrastructure are available.

After the researchers see the condition of Kapoposang Island, which is a government asset managed by the PT.MTW, there are many changes found and they has been managed quite well. The private sector was not only concerned with the tourist destination, but also contributes well to the community in the form of utilization of community services by maintaining tourist areas, marine conservation, as well as providing the assistance in the form of street lighting, toilet, health and education assistance. Seeing that the contribution given by the private sector in managing a very large island, as society perceived, dictated by one resident:

\begin{abstract}
"... since PT.MTW came in, we are very happy, because they pay attention to us, eventhough we are not working in their tourist place. A lot of help is given, for example; street lighting, turtle conservation, marine biota care which they did every month or in certain month. At holiday, for example, they come to provide health assistance and distributing new books to the children. While local governments are rarely want to come here, but people from the PT.MTW come here often ... "(interview, May 4, 2016).
\end{abstract}

Directly, the community perceives the contribution of partnership established in the form of assistance from the private sector. Moreover, the PT. MTW conducts community empowerment according to its potential and needs, so that in the end community would be able to rely on themselves. Although in Kumar's theory, the most influential factor is the BOT Consession which means that the private sector as the manager is willing to provide facilities and infrastructure, but they also need the help and support from the Pangkep Local Government. In partnership, a partner do not charge one party in the provision of public services, but demand each party to be involved in the welfare of island communities.

Based on the results of the research, it showed that there are several benefits gained since cooperation in marine tourism management began. From the side of the Government (Department of Culture and Tourism) the benefits gained are the inputs in the form of contributions for increasing PAD, maintaining public facilities, the nurturing maritime island of Kapoposang island, as well as ensuring the welfare of the island community. While for the Private (Makassar Makassar Tirta Wisata / Makassar Diving Center), the benefits obtained in accordance with the vision of the mission to achieve the goal of maintaining the area of tourism, especially coral reefs in the marine area on the island of Kapoposang, which became one of the well known underwater tourist destination in Indonesia. They are also ensuring the welfare of the community by using the services in managing and maintaining the marine tourism area. Similarly, the community of Kapoposang Island gained benefits from the presence of partnership between the local government and PT. MTW. They get the authority to participate in maintaining the island of Kapoposang, achieving prosperous community life thanks to abundant sea products, so that the welfare of the island's community is increased. This is in line with the results of research by Fitri et al. (2015) which stated that the development of tourism destinations can improve the quality of life of the community as a whole. The maintenance of a useful tourism destination supports the success of government programs and creates an independent community, which they would be able to determine their needs, to make a plan and carry out activities on the island with the full support of the Pangkep government and PT Makassar Tirta Wisata.

Informant (initials name SA) as tourists, explained the opportunities and challenges 
obtained by each party:

\begin{abstract}
"... Kapoposang Island is an ideal place for marine tourism. It is a beautiful place and we can not use the Cell phone because the signal is low/unreachable. However, it is difficult to come here due to transportation access, and if you want to enjoy the tour, you must register at PT.MTW and the cost is very expensive. If we want a backpacker style, we can follow the fishing boat and circling the island, but we can not enter the tourist area "... (interview May $4,2016)$
\end{abstract}

The maritime tourism potential of Kapoposang Island is very strategic but it is constrained by transportation to the island. However, if viewed from the results of partnership various expectations and basic needs of society has been fulfilled, such as the availability of lighting, health centers, and educational facilities. Outcomes in the socio-economic improvement in society are very satisfying. The level of community life on the island is classified as medium (not too poor nor rich) and people feel the increase of welfare. Until now, people are not dependent on tourists visit, but utilize the sea to be processed, maintained and cultivated well by involving the private sector for the future survival of Kapoposang Island community.

Based on interviews and observations from the study sites, the partnership pattern established is not only bring the profit but raises a new issue which is rarely highlighted by the Pangkep government. That issue is the social strata which showed the opposite result compared to the increasing and improving economic strata of the island community. They have low/minimum health and education. These are miserable problems on the island, not to mention the distant access from the city/regency to the island, and also a few number of teachers and medical personnel availability who rarely come to carry out their duties as educators and health services. This causes Kapoposang Island children as the future hope and success of families, nations and countries on the island, prefer to become fishermen from generation to generation.

\section{Conclusions}

The research on Public-Private Partnership in Kapoposang Island management through cooperation run by government of Pangkep with PT. Travel Tirta Makassar focused on management and empowerment of nautical tourism, while PT.MTW preserved marine nature for the survival of society. The improvement of Kapoposang Island's environmental conditions has been very well felt by the community, especially the fishermen who gained the abundant catch of fish when coral reefs and marine are well guarded and protected. The contribution earned by the local government or the profit earned by the private sector decreases every year, due to the difficulty of crossing access and the high cost of visiting Kapoposang Island tourism destination. From the implementation of this established partnership raises new problems as well as new tasks for government and private parties together to fix three very critical problems. First, transportation access to Kapoposang Island which is difficult and expensive, causing the decrease of local and foreign tourists. Secondly, the poor education of chilldren in Kapoposang Island, the teachers who are appointed to civil servants and should serve on the Island but left the island and walked away from their responsibilities. Finally, health services for the islanders are concerning very sad. We can get free service in town, but it is only happen once in every three months in Kapoposang island. These three problems should become a superior program for local government of Pangkep regency, in order to balance the increasing prosperity of the Island community with the access to education and health in achieving a better future.

To get the most benefit from the partnership of marine tourism management in Kapoposang Islands, the parties can do several things, among others: improving the facilities and access of land transportation in the archipelago, sea transportation between Islands and the surrounding area with low cost, improving facilities and basic education infrastructure on the Island, access to education at the secondary school level around the Island especially in Pangkep City. In addition, it should provides special incentives for teachers to raise awareness and discipline in carrying out their main duties and functions as educators, improving facilities and infrastructure of health services on the island, facilitating access to health in the surrounding areas especially in Pangkep City, and providing special incentives for medical personnel to encouraging awareness and discipline to carry out their main duty and function as a health service in Kapoposang Island.

\section{References}

Abriany (2002). Kemitraan Dalam Pelestarian Bangunan Bernilai Sejarah dan Budaya, Master Thesis. Bandung: ITB. 
Alfen, H. W. (2009). Public Private Partnership In Infrastructure Development: Case Studies From Asia and Europe. Berlin: Weimar.

Asker, S., Boronyak, L., Carrad., N., Paddon, M. (2010). Effective Community Based Tourism a Best Practice Manual. Sydney: Sustainable Tourism Cooperative Research Center.

Fitri, D. A, Fabdeli, Sudarmadji (2015). "Perkembangan Destinasi Pariwisata dan Kualaitas Hidup Masyarakat Lokal". MIMBAR: Jurnal Sosial dan Pembangunan 31 (2): 339-350

Grimsey, D. \& Lewis, M. K. (2004). Public Private Partnership: The World Revolution in Infrastructure Provision and Project Finance. London: Edward Legar. Inc.

Haryani (2014), "Potensi Pengembangan Atraksi Wisata Kampung Nelayan Pasie Nan Tigo Padang di Tengah Ancaman Bencana Abrasi". MIMBAR: Jurnal Sosial dan Pembangunan 31 (2): 189-198.

Haussler, N \& Strasdas W. (2002). Training Manual for Community Based Tourism. Berlin: Inwen.

Huberman, M. (1992). Analisis Data Kualitatif: Buku Sumber Tentang Metode-Metode Baru, Tjetjep Rohendi Rohidi (trans), Jakarta: UI Press.

Kumar, S \& C. J. Prasad. (2004). Public-Private
Partnership in Urban Infrastructure. New Delhi: Kerela Calling.

Osborne D, \& Ted G. (1992). Reinventing Government: How the Entrepreneurial Spirit is Transforming the Public Sector. Addison-Wesley.

Parente W. J. (2006). "Public Private Partnerships" in Workshop on "Fundamental Principles and Techniques for Effective Public Privat e Partnerships in Indonesia", 1-3 November 2006 in Jakarta.

Permendagri No.17 tahun 2007 tentang Pedoman Pengelolaan Teknis Barang Milik Daerah

Ramelan, R. (1997). Kemitraan Pemerintah Swasta dalam Pembangunan Infrastuktur. Yogyakarta: Pustaka Pelajar.

Savas, E. S. (1987). Privitization: The Key of Better Government. New Jersey: Chatam House Publisher.

Schubeler, P. (1996). Participation and Partnership in Urban Infrastructure Management. Washington: The World Bank.

Selamat, M. D. (2013). "Penerapan Prinsip Good Governance dalam Penyelenggaraan Pemerintahan Daerah (Suatu Studi pada Sekretariat Daerah Kabupaten Kepulauan Siau Tagulandang Biaro)". Governance vol. 5 no. 1 : 56-65. 